Cornell Law Library

Scholarship@Cornell Law: A Digital Repository

Cornell Law Faculty Publications

Faculty Scholarship

4-1-1994

\title{
Perceptions of Civil Justice: The Litigation Crisis Attitudes of Civil Jurors
}

Valerie P. Hans

Cornell Law School, valerie.hans@cornell.edu

William S. Lofquist

Follow this and additional works at: http://scholarship.law.cornell.edu/facpub

Part of the Civil Procedure Commons, $\underline{\text { Courts Commons, Litigation Commons, and the Torts }}$ Commons

\section{Recommended Citation}

Hans, Valerie P. and Lofquist, William S., "Perceptions of Civil Justice: The Litigation Crisis Attitudes of Civil Jurors" (1994). Cornell Law Faculty Publications. Paper 320.

http://scholarship.law.cornell.edu/facpub/320

This Article is brought to you for free and open access by the Faculty Scholarship at Scholarship@Cornell Law: A Digital Repository. It has been accepted for inclusion in Cornell Law Faculty Publications by an authorized administrator of Scholarship@Cornell Law: A Digital Repository. For more information, please contact jmp8@cornell.edu. 


\title{
Perceptions of Civil Justice: The Litigation Crisis Attitudes of Civil Jurors
}

\author{
Valerie P. Hans, Ph.D., and William S. Lofquist, \\ Ph.D.
}

\begin{abstract}
Public perceptions that the civil justice system is in crisis are apparently widespread, but little is known about the causes or correlates of such views. This article analyzes the litigation crisis attitudes of a sample of civil jurors. Like the public, jurors endorsed a number of statements suggesting that there is a litigation crisis. Factor analysis identified two independent components: general concern over excessive litigation, and criticism of the civil jury. Litigation crisis views were found in all demographic and attitudinal subgroups. However, attitudes about the civil justice system were related to the respondent's political efficacy, claims consciousness, belief in a just world, age, religion, and race.
\end{abstract}

There is a veritable explosion of litigation in the United States that threatens to undermine the very fabric of our society. Or is there? Some book-length treatments of the issue argue that there have been dramatic increases in civil filings and in jury awards over the last decade (Huber, 1988; Olson, 1991). Advertising campaigns by the insurance industry have blamed increased insurance costs and lesser availability of business and medical insurance on an explosion of litigation and rising jury awards (see Daniels, 1989, for presentation of the themes of several ad campaigns). Former Vice President Danforth Quayle exploited the alleged litigation crisis for political advantage when he used it to argue that excessive litigation was undermining American competitiveness (Quayle, 1991; see Hensler, 1992). Assumptions of crisis have fueled the movement for tort reform, which swept through state legislatures in the late 1980 s and resulted in legal changes (Sanders \& Joyce, 1990).

Yet many researchers question whether or not there has been a general explosion of litigation (Daniels, 1989; Daniels \& Martin, 1986; Galanter, 1983, 1986; Hensler, 1992; Saks, 1986, 1992). These scholars point out that careful analysis of court filings shows increases over time are limited to certain types of high visibility cases such as product liability, that increases can often be explained by other factors such

Valerie P. Hans, Ph.D., is Professor of Criminal Justice and Psychology at the University of Delaware. William S. Lofquist, Ph.D, is Assistant Professor of Sociology at State University of New York at Geneseo. Research and writing were supported by National Science Foundation grants SES8822598 and GER9350498. The authors wish to thank Dorothy Kagehiro, Gary Moran, and Neil Vidmar for comments on an earlier draft. Address reprint requests and correspondence to Professor Hans, Criminal Justice Program, Department of Sociology and Criminal Justice, University of Delaware, Newark, DE, 19716, USA. 
as population expansion or government actions, and that some categories of cases have actually decreased, all of which suggest no overall explosion of litigation. Furthermore, studies of injuries and subsequent claiming show that only a small number of injuries ever result in legal action, casting doubt on the notion that Americans are an overly litigious people (see generally Grossman \& Trubek, 1981).

Whether or not a litigation crisis exists, public opinion polling indicates that most Americans believe that there has been a litigation explosion, and that as a result the courts and insurance industry are in crisis (Fleming \& Schwarz, 1991; Hans, 1993; Taylor, Kagay, \& Leichenko, 1987; The Public Pulse, 1991). In a 1986 national survey conducted by Louis Harris and Associates for Aetna Life and Casualty, many respondents reported believing that more people bring lawsuits than should, that over the prior decade the number of personal injury lawsuits grew faster than the population, and that the size of awards had increased faster than inflation (Taylor et al., 1987). Forty-five percent of the national sample believed that the size of most awards in personal injury cases had been "excessive," compared to $28 \%$ who described them as "about right" and $16 \%$ as "not enough." Similar concerns were voiced in a 1991 national survey conducted by the jury consulting firm, Metricus, in which $68 \%$ of the respondents stated that "juries today are awarding too much money" (Fleming \& Schwarz, 1991).

Such perceptions and attitudes about excessive litigation appear to be important factors in civil jury judgements. In a recent study of tort jurors in business cases, Hans and Lofquist (1992) found a significant correlation between litigation crisis attitudes and jury awards. Those juries whose members expressed greater belief in a litigation crisis gave lower awards. In post-trial interviews, jurors frequently cited the litigation explosion and the need to control runaway costs as reasons they decided on lower awards. These jurors placed themselves in the position of imposing limits, through their modest awards, on a system they perceived as excessively generous to undeserving plaintiffs. Similarly, Vidmar (1992) interviewed jurors in medical malpractice trials and found them deeply concerned about excessive litigation and insurance costs.

The linkage between views of a litigation explosion and jury behavior has been confirmed with mock juries. Greene, Goodman, and Loftus (1991) conducted a mock jury study with members of a Washington state jury pool. They found that the jurors' attitudes about tort reform, about the influence of the media on jury awards, and about the credibility of attorneys were significantly correlated with their damage awards in a personal injury case. Those jurors who responded in ways that generally supported tort reform gave lower awards. Similarly, Astolfo (1991) found that Dade County, Florida residents who favored tort reform recommended lower compensation for a hypothetical plaintiff suing a corporation for injuries than residents who were less favorable to tort reform. Although the correlational nature of these studies precludes causal inferences, Loftus (1979) used an experiment to determine how exposure to insurance company advertising about the negative impact of high awards affected jury judgments. She found that mock jurors exposed to such advertising awarded less money for pain and suffering than mock jurors who had not read the advertising. 


\section{CONTRIBUTIONS OF A PSYCHOLOGICAL PERSPECTIVE: EXPLAINING LITIGATION CRISIS ATTITUDES}

The perception of a litigation crisis is an interesting psychological phenomenon, yet little is known about it. Is it primarily the result of a well-orchestrated business and insurance industry advertising campaign and biased media coverage, as Daniels (1989) asserts? Is the predisposition to perceive runaway litigation linked to a person's life experiences, demographic characteristics, or other attitudes and values? Who among the public tends to be more believing in a litigation explosion?

The purpose of this paper is to explore litigation crisis attitudes in more detail. First, the paper presents attitudinal data from a sample of 269 civil jurors, which show there is widespread belief among jurors that the civil justice system is in trouble. A factor analysis is employed to analyze the structure of a scale of litigation crisis attitudes.

Other analyses are undertaken to explore the demographic and attitudinal correlates of these litigation crisis attitudes. National opinion polls have discovered that public knowledge about the courts is generally low (Sarat, 1977), but varies among demographic subgroups. In one survey, whites, higher income respondents, and those with more education were more familiar with the courts than blacks and those with less income and education (Yankelovich, Skelly, \& White, 1978). Interestingly, in the same survey, people who had more knowledge about the courts also expressed less confidence in them. In the Harris survey, which focused specifically on the civil justice system (Taylor et al., 1987), no statistical analyses were presented, but it appeared that people with higher levels of education and income, professionals, business proprietors, and older people found most fault with the civil justice system. The report noted that although it is unusual to find high status respondents most disaffected with the status quo, it is possible that these groups were more likely to be informed about the workings of the civil justice system, or believed that they were more likely to be sued, compared to other demographic groups. Thus it was of interest to examine whether litigation crisis attitudes varied by such factors as age, gender, race, income, and education.

A novel contribution of this study is that we employed a number of existing attitudinal scales to assess their relationship to litigation crisis views. One psychological predisposition that is examined is Vidmar and Schuller's (1987) construct of "claims consciousness." They describe claims consciousness as the awareness of the violation of one's rights and the propensity to claim when those rights have been violated. Vidmar and Schuller developed and validated a Claims Consciousness scale, containing a set of self-descriptive attitudinal pairs, that predicted people's disputing behavior and their preferences for adjudication over mediation. People high on claims consciousness tended to report consumer and other problems more frequently, were more likely to have consulted lawyers and other organizations about their problems, and preferred more adversarial methods to resolve their disputes. In the present study, we attempted to determine whether people high on claims consciousness were also more willing to grant legitimacy to the claims of others.

A second psychological variable is locus of control. The National Jury Project (1992) asserts that people can be distinguished in terms of their tendency to rely on either individual or social factors in attributing causation and responsibility. In 
jury selection research in civil cases, National Jury Project investigators discovered that prospective jurors could be classified along a continuum. At one end is the "personal responsibility" adherent, who tends to attribute the causation of events to the individual, emphasizes motivation and self-reliance, and tends to blame victims for their own injuries. At the other end is the individual with a "social responsibility" perspective, who looks to environmental and social forces as causes of injury. Although we could not locate an existing scale that tapped the tendency to attribute injury causation to the person versus the situation, the locus of control construct is conceptually related, and one of the several available scales was chosen to measure this psychological trait (see generally Lefcourt, 1981-1984).

Views of civil litigation might also be related to the belief in a just world. In a number of studies, perceptions that the world is just, and that people deserve what they get, have been found to relate to less sympathetic views of the victims of injury. Theorizing about the tendency to hold victims personally responsible for their injuries, social psychologist Melvin Lerner (1980) has argued that people need to believe in a just, predictable, and controllable world. The undeserved suffering of innocent victims challenges that belief. Strategies of derogating the victim, minimizing the injury, and reinterpreting the cause of the injury as victim-precipitated can serve to redefine the event and preserve both the belief in a just world and a sense of self-control. Thus, one hypothesis would be that people with a strong belief in a just world might be more likely to hold litigation crisis attitudes because of their greater tendency to derogate tort plaintiffs and to see their claims as questionable. On the other hand, people who believe in a just and predictable world may be less inclined to see a legal system out of control, with undeserving plaintiffs receiving high awards. Just world jurors may be more satisfied and complacent about the system, confident that it is delivering reasonable awards to deserving victims.

The personality construct of authoritarianism, which is characterized by respect for authority and a punitive approach to deviance, has been found to relate to attitudes toward criminal defendants (for recent demonstrations see Moran \& Comfort, 1982; Narby, Cutler, \& Moran, 1993). Thus it was of interest to determine whether the influence of authoritarianism extended to the civil justice realm. A number of differences between the civil and criminal justice systems, including the more prominent role of the state and the more deviant status of the criminal defendant, would suggest that authoritarianism's effect on attitudes toward the civil system might be muted. Yet at least one study (Delisa, Moran, \& Cutler, 1992) has shown a linkage between tort reform attitudes and reactions to criminal defendants, with people who favored tort reform holding more punitive orientations toward criminal defendants.

The final attitudinal scale we employed was one that tapped the juror's subjective sense of political efficacy. The scale we employed to measure this psychological construct was originally developed by Campbell, Gurin, and Miller (1954) to gauge the extent to which people believe political change is possible through citizen efforts. It was of interest for us to observe how jurors, who had just participated directly in the political process through jury service, responded to the scale. A strong sense of political efficacy should mitigate the perception that the litigation system is in crisis. Political efficacy is correlated with trust in government (Acock \& Clarke, 1990). Therefore it is likely to be associated with confidence that the legal system, like other aspects of the political process, is responsive to citizen complaints. 


\section{METHOD}

\section{Participants}

The attitudinal data come from an interview study of civil jurors in business cases. During a one-year period at a northeastern state trial court of general jurisdiction, we identified every civil jury trial that had a business or corporate party. Cases that settled during trial, and two cases involving conflicts of interest, were excluded. The study also included one pretest case that fell outside the one-year period. All of the trials in the study, including the pretest case, occurred during the time period 1989-1991.

With the judges' permission, the names, addresses, and telephone numbers of jurors who decided the cases in the study were obtained from court files. These jurors received a letter on university stationery, requesting that they participate in an interview study about their jury experience. They were informed that an individual from the Jury Project would be contacting them by telephone to determine whether they would be willing to participate in the study. The initial letter was followed by a telephone call to the juror. Jury Project staff made up to ten telephone calls and sent two additional letters to try to reach the jurors and determine whether they would participate. Only a small minority of jurors could not be contacted by these methods. The overall response rate was $64 \%$, with approximately 7 out of every 12 jurors from each case taking part in the study. A total of 269 jurors from 36 different cases, including 28 tort cases and 8 contract cases, participated. ${ }^{1}$

The jurors' demographic characteristics were as follows: $54 \%$ were female, and $90 \%$ were Caucasian, with the majority $(66 \%)$ married. The jurors' ages ranged from 20 to 75 , with a mean of 44 years. As for education, $6 \%$ had less than a high school degree, and $37 \%$ had graduated from high school, with the remainder having some college (28\%), a college degree $(22 \%)$ or graduate training $(6 \%)$. Most were either Protestant $(45 \%)$ or Catholic $(39 \%)$. Asked to identify their political orientation, $34 \%$ of the jurors described themselves as conservative, $36 \%$ as moderate, and $30 \%$ as liberal. The mean household income was between $\$ 30,000$ and $\$ 40,000$.

Compared to the group of jurors who did not participate in the interview study, the study participants included significantly fewer nonwhite jurors $\chi^{2}(1)=16.19$, $p<.01$ ), more jurors with higher educational levels $\left(\chi^{2}(4)=11.61, p=.02\right)$, and more jurors with higher status occupations such as managerial, professional, or technical jobs $\left(\chi^{2}(1)=8.79, p<.01\right)$. Jurors' evaluative ratings of their jury experience did not differ for participants and nonparticipants.

\section{Procedure}

Following a semi-structured interview about jurors' reactions to their cases, jurors filled out an extensive questionnaire. The questionnaire included items about their attitudes toward civil litigation, business, and other social attitudes. Positive and negative phrasings of key attitudinal items were employed to control for agreement

\footnotetext{
1 Attitudinal data from 141 jurors in 18 of these tort cases are reported in Hans and Lofquist (1992); responses to litigation crisis items were formed into a scale, which was significantly related to jury awards. This article uses data from the entire sample and undertakes new analyses.
} 
response bias. Most questions were answered on a five-point scale, ranging from 'Strongly Agree' to 'Strongly Disagree,' with a midpoint labeled 'Neither Agree Nor Disagree.' The majority of jurors filled out the questionnaire immediately after the interview, while others completed the questionnaire at a later time and mailed it in.

\section{Questionnaire Items}

Items tapping attitudes toward litigation are presented verbatim in Table 1 . To enable us to explore the relationships among different types of attitudes, the juror questionnaire also contained items from a number of attitudinal scales. Time constraints on the jurors, who participated in a lengthy interview prior to filling out the questionnaire, prevented us from using complete attitudinal scales. As a tradeoff, we included subsets of items from a variety of established scales, using individual items that prior work showed had the strongest correlations with the complete scales.

\section{Claims Consciousness}

In the current study, a 7-item Claims Consciousness scale (alpha $=.65$ ) included all but one of the 8 items in the original scale developed by Vidmar and Schuller (1987, Study 3). A substantial number of jurors in our study reported difficulty with one of the original items (blame myself-blame the other person) and thus it was deleted from our scale. Items on the scale included the following attitude pairs: competitive-not competitive; assertive-not assertive; aggressive-not aggressive; risk taker-not a risk taker; prefer compromise-prefer winning; willing to complain-not willing to complain; outspoken-careful about hurting other people's feelings. Jurors circled the adjective from each pair that best described them. Responses were scored so that higher numbers indicated higher claims consciousness.

\section{Locus of Control}

A good deal of research on the reliability and validity of locus of control scales has been undertaken, with mixed results (Lefcourt, 1981-1984). We were governed by our need for a short and reliable scale. Levenson (1981) reconceptualized Rotter's Internal-External scale and was able to distinguish three independent dimensions: Internality, or the extent to which people believe that they have control over their own lives; a Powerful Others dimension, which deals with the impact that others in positions of power may have on one's own life; and the Chance dimension, which taps the perceived role of chance in life. We decided to include the internality subscale items, since they were closest theoretically to the notion of personal control. Eight items comprising the Internality subscale of Levenson's (1981) Locus of Control scale were employed in the current study, and formed our Locus of Control scale (alpha $=.65$ ). Items included were: "Whether or not I get to be a leader depends mostly on my ability;" "Whether or not I get into a car accident depends mostly on how good a driver I am;" "When I make plans, I am almost certain to make them work;" "How many friends I have depends on how nice a person I am;" "I can pretty much determine what will happen in my life;" "I am usually able to protect my personal interests;" "When I get what I want, it's usually because 
I worked hard for it;" and "My life is determined by my own actions." Respondents indicated agreement or disagreement on six-point scales, with higher numbers indicating greater internal locus of control.

\section{Authoritarianism}

Six questions tapped authoritarian attitudes. They included: "One good way to teach certain people right from wrong is to give them a good stiff punishment when they get out of line;" "Obedience and respect for authority are the most important virtues children can learn;" "If a child starts becoming a little too unconventional, the parents should see to it that their child returns to the normal ways expected by society;" "Organizations like the army and priesthood have a pretty unhealthy effect upon men because they require strict obedience of commands from supervisors;" "Rules about being well-mannered and respectable are chains from the past which we should question very thoroughly before accepting;" and "Capital punishment should be thoroughly abolished."

Although it has been a popular construct, it has proven difficult to obtain highly valid and reliable scales that reflect the personality construct of authoritarianism. The alpha for the six items that were employed in the current study was .50, an acceptable level given past history with this personality trait.

\section{Fust World}

To develop a short set of items reflecting Just World beliefs for inclusion in our survey, we consulted with social psychologist and Just World scholar John Ellard. In unpublished research, he obtained responses from approximately 1,000 subjects to a large number of Just World items, and subjected the responses to extensive correlational and scale development analyses. In the current questionnaire, we included the top 7 items that Ellard found had the highest correlations with the Just World scale in his project. In our project, during reliability analyses of the jurors' responses, we deleted one item that had only a small correlation to the total scale scores, leaving 6 items for a Just World scale (alpha $=.52$ ). These items were: "When parents punish their children, it is almost always for good reasons;" "It is rare for an innocent person to be wrongly sent to jail;" "Students almost always deserve the grades they receive in school;" "It is often impossible for a person to receive a fair trial in this country;" "Basically, the world is a just place;" and "By and large, people deserve what they get."

\section{Political Efficacy}

Political scientists have used somewhat different sets of items to tap political efficacy (see e.g., Acock \& Clarke, 1990; Aish \& Joreskog, 1990; Campbell et al., 1954; Renshon, 1974). We used the five-item scale developed by Campbell et al. (1954). After deletion of two items that have been found to be problematic in other research (Renshon, 1974), the three remaining items had an acceptable alpha of .61. They were: "I don't think public officials care much about what people like me think;" "People like me don't have any say about what the government does;" and "Some- 
Table 1. Civil jurors' litigation crisis attitudes

\begin{tabular}{|c|c|c|c|c|c|}
\hline Item & SA & A & $\mathrm{N}$ & D & SD \\
\hline Q1. There are far too many frivolous lawsuits today. & 28 & 55 & 12 & 5 & 0 \\
\hline Q2. People are too quick to sue, rather than trying to solve disputes in some & & & & & \\
\hline 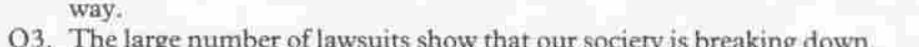 & 18 & 62 & 13 & 6 & 1 \\
\hline $\begin{array}{l}\text { Q3. The large number of lawsuits show that our society is breaking down. } \\
\text { O4. The money awards that juries are awarding in civil cases are too large. }\end{array}$ & 3 & 27 & 31 & 35 & 5 \\
\hline $\begin{array}{l}\text { Q4. The money awards that juries are awarding in civil cases are too large. } \\
\text { O5. Most people who sue orhers in court have legitimate grievances. }\end{array}$ & 8 & 29 & 39 & 21 & 3 \\
\hline Q5. Most people who sue others in court have legitimate grievances. & 2 & 33 & 36 & 29 & 1 \\
\hline $\begin{array}{l}\text { Q6. By making it easier to sue, the courts have made this a safer society. } \\
\text { Q7. Juries do a good job determining the outcomes of lawsuits and assessing }\end{array}$ & 1 & 6 & 23 & 58 & 12 \\
\hline damages. & 5 & 56 & 24 & 14 & 2 \\
\hline
\end{tabular}

Note. Numbers represent the percentage of 269 jurors giving each response. Responses are: Strongly Agree (SA); Agree (A); Neither Agree nor Disagree (N); Disagree (D); and Strongly Disagree (SD).

times politics and government seem so complicated that a person like me can't really understand what's going on." All three of these items are commonly used to assess political efficacy (see Acock \& Clarke, 1990). Responses were coded so that higher numbers indicated a greater sense of political efficacy.

\section{Demographic Variables}

Demographic information was obtained from court records and juror questionnaires, including gender, race, age, educational level, marital status, income, religion, and whether or not the juror had ever been a member of a union.

\section{RESULTS}

\section{Attitudes Toward Litigation}

To analyze jurors' perceptions of litigation, 7 items pertaining directly to the legitimacy or excessiveness of civil litigation were used. Jurors' responses to these questionnaire items about the legitimacy of civil lawsuits showed considerable skepticism toward plaintiffs and civil litigation.

Table 1 displays the frequencies of responses to all 7 items. Jurors revealed predominantly negative views about the frequency and legitimacy of civil lawsuits. Approximately four out of every five jurors asserted that "There are far too many frivolous lawsuits today" and believed that "People are too quick to sue, rather than trying to solve disputes in some way." Just a third of the jurors thought that "Most people who sue others in court have legitimate grievances." Jurors repudiated the statement that "By making it easier to sue, the courts have made this a safer society" by a ten-to-one margin. However, only a minority believed that "The large number of lawsuits show that our society is breaking down."

The questionnaire responses showed greater support among the jurors for the institution of the jury. Six out of ten jurors agreed that "Juries do a good job determining the outcomes of lawsuits and assessing damages." However, more people agreed than disagreed that jury damage awards were too high.

Responses were recoded so that higher numbers on each item indicated greater belief in a litigation crisis. They were then formed into a 7-item Litigation Crisis scale (alpha $=.65)$ for use in subsequent analysis. 
Table 2. Litigation crisis scale: Factor matrix after varimax rotation

\begin{tabular}{lccc}
\hline Variable & Factor 1 & & Factor 2 \\
\cline { 2 - 3 } & Excessive litigation & & Jury criticism \\
\hline Q2. People too quick to sue. & .75 & .12 \\
Q6. Suits make society safe. & .66 & -.24 \\
Q1. Too many frivolous suits. & .66 & .27 \\
Q5. Most suits legitimate. & .50 & .38 \\
Q3. Suits show society breakdown. & .46 & .29 \\
Q7. Juries do good job. & -.06 & .80 \\
Q4. Jury awards too large. & .30 & .64 \\
\hline
\end{tabular}

Note. For exact wording of items see Table 1. Responses were recoded so that higher responses indicated more negative views about litigation.

\section{Factor Analysis}

The Litigation Crisis scale was subjected to factor analysis to determine if one or more independent factors were operative. A principal components analysis extracted two factors with eigenvalues of more than 1.0; these factors accounted for a total of $49 \%$ of the variance, indicating a moderately good fit. Varimax rotation was employed to enhance the interpretability of the factors. The rotated factor matrix is presented in Table 2 .

Factor 1 (eigenvalue = 2.35), labeled Excessive Litigation, accounted for $34 \%$ of the variance. Beliefs that people are too quick to sue, that there are too many frivolous lawsuits, and disagreements that the rise in lawsuits has increased societal safety all loaded strongly on this factor. The second factor (eigenvalue $=1.06$ ), labeled Jury Criticism, accounted for just $15 \%$ of the variance. The 2 items loading most strongly on this factor both related to the jury's soundness in deciding verdicts and damage awards. Thus, independent perceptions of the worth of litigation and the ability of the jury contributed to litigation crisis judgments.

\section{Relationship of Litigation Crisis Views to Attitudinal Variables Claims Consciousness}

One interesting question is how claims consciousness relates to juror perceptions that there are frivolous lawsuits. Does the apparently heightened awareness of rights and willingness to claim extend to others' grievances, or is it more self-focused? Claims Consciousness correlated modestly but significantly with perceptions of a litigation crisis $(r=.13, p<.05)$. The correlation was positive, indicating that the more that individuals were aware of and willing to pursue their own claims, the more likely they were to perceive others as having illegitimate claims. Rather than representing a broad awareness and sensitivity to one's own and others' rights, claims consciousness, at least as measured by this scale, is more focused toward the self and how one has been wronged by others. Those who are less likely to claim for themselves appear to be more willing to grant legitimacy to the claims of other citizens. This finding suggests a perception among the highly claims-conscious of a zero-sum game of litigation, in which the number of successful lawsuits is limited. 


\section{Locus of Control}

Another set of attitudes that might well relate to the perception of frivolous lawsuits is the locus of control construct. As outlined earlier, the belief in personal control over life events may predispose observers to take a negative view of plaintiffs who sue others for injury. However, in this study, the Internality subscale for the Locus of Control test was unrelated to the Litigation Crisis scale $(r=-.09, n s)$. It is unfortunate that we were not able to include items from Levenson's (1981) other two subscales measuring the perceived impact of powerful others or the role of chance, since these factors could have been associated with judgments about civil litigation.

\section{Authoritarianism}

Authoritarianism was also uncorrelated with Litigation Crisis attitudes $(r=.09$, $n s)$. It is possible that a more extensive set of items would have revealed a relationship. However, there are good reasons to think that civil and criminal parties might be evaluated differently by the authoritarian person. Civil justice litigants are not as strongly associated with deviance as criminal defendants, and in most civil litigation the state, a potent symbol of authority, is not a party. In the present study, most of the cases involved moderately-sized regional or local businesses. It might be that in certain types of civil lawsuits, such as litigation against the government or a large business, authoritarianism would be associated with more negative perceptions of plaintiffs.

\section{Fust World}

The Just World scale correlated significantly, but in an unexpected direction, with Litigation Crisis attitudes $(r=-.13, p<.05)$. Jurors who believed in a just and predictable world, where people get what they deserve, were less likely to see a litigation crisis and less likely to endorse the notion that there were a large number of illegitimate lawsuits. Jurors who endorsed the idea of a just world were thus more likely to express faith in the existing tort system. To provide confirmation that the Just World result was caused by a greater degree of support for the system, rather than some other dimension such as differential response to victims, we correlated Just World scores with responses to a question on confidence in the courts. We found a positive and significant $r$ of $.24(p<.001)$, confirming that those who believe in a just world are more likely to express confidence in the courts.

\section{Political Efficacy}

The final attitudinal scale we employed was one that tapped the juror's subjective sense of political efficacy (Campbell et al., 1954). The Political Efficacy scale scores related significantly to the Litigation Crisis scale scores $(r=-.22, p<.01)$. The relationship was negative, indicating that those who felt most politically efficacious were least likely to believe that there was an explosion of litigation. Greater confidence in the political system, and in their own ability to effect change, led these jurors to conclude that mechanisms existed to control the courts. It seems reasonable that a sense of personal alienation and a perceived inability to have mean- 
ingful input into the political process that characterize jurors with low political efficacy scores might also lead them to believe that the courts are out of control.

\section{Political Identification}

One item was employed to determine political self-identification. Jurors were asked, "When it comes to politics, how do you think of yourself?" They responded on a 7-point scale, which ranged from extremely liberal to extremely conservative. Political identification was unrelated to Litigation Crisis attitudes $(r=.07, n s)$.

\section{Demographic Variables and their Relationship to Litigation Crisis Attitudes}

Of the demographic variables that were examined, just two factors related significantly to Litigation Crisis views. The first was age $(r=.13, p<.05)$. The older the respondents, the more likely they were to perceive that the courts were filled with illegitimate lawsuits and that awards were too high. Inspection of the mean Litigation Crisis scale scores for different age groups showed that generally there was a gradual, modest progression upward from the youngest to the oldest age groups. For example, jurors under the age of 26 had a mean score of 22.37 , compared to a mean of 24.45 for jurors over 65 years of age. Other age groups fell in between $(F(2,259)=2.86, p=.06)$.

The second demographic variable that related to Litigation Crisis attitudes was religion. Protestants $(M=23.98)$ had higher Litigation Crisis scale scores than did Catholics $(M=22.62)$, those indicating other religious preferences $(M=$ $22.67)$, and those stating no religion $(M=22.77)$. A one-way analysis of variance comparing Litigation Crisis scores for Protestants versus non-Protestants revealed a significant difference $(F(1,256)=9.99, p<.001)$.

\section{Regression Analysis}

A regression analysis was conducted to assess the extent to which attitudinal and demographic factors were able to predict Litigation Crisis scores. Dichotomous factors were coded as dummy variables. Because of small cell sizes for some of the religion categories and the comparability of the responses of non-Protestant groups, religion was categorized as a dummy variable indicating that the respondent was either a Protestant or a non-Protestant. Because of small cell sizes for different racial and ethnic minorities, the juror's race was coded as either white or nonwhite.

In general, the regression equation was only modestly successful in predicting the Litigation Crisis scores, reflecting the small sizes of the correlations between Litigation Crisis attitudes and the attitudinal scales and demographic factors presented above.

A stepwise regression analysis included both demographic and attitudinal factors as predictor variables and Litigation Crisis scores as the dependent variable. The first item to be entered was Political Efficacy $(R=.23)$, explaining $5 \%$ of the variation in litigation crisis views, with those with a low sense of political efficacy more likely to hold Litigation Crisis ideas. On the second step, religion entered the equation, increasing the $R$ to .29 and the $R^{2}$ to .09 . Protestants were more 
apt to hold Litigation Crisis attitudes. The juror's race entered as a significant predictor variable on the third step, explaining an additional $3 \%$ of the variance, with whites expressing more belief in a litigation crisis. On the final step, the juror's Just World scores were added as a significant predictor, with low belief in a just world associated with Litigation Crisis views. This final step brought the $R$ to .36 and the percent of the variation explained to $13 \%$.

\section{DISCUSSION}

The attitudes of jurors show widespread belief in a litigation explosion and concerns about the legitimacy of civil lawsuits. The pervasiveness of these beliefs is perhaps the most striking finding of our study. Litigation crisis attitudes are abundant in all sectors of society. The analysis reported here revealed two independent factors integral to these attitudes, a general factor reflecting concern over excessive litigation, and a second factor that focused on the performance of the civil jury.

Turning to the determinants of litigation crisis views, the analysis found correlations with a number of attitudinal and demographic variables. Litigation Crisis scores were found to be related to the attitudinal scales tapping Claims Consciousness, Belief in a Just World, and Political Efficacy, and the demographic factors of age, religion, and race. Jurors who believed most strongly that the litigation system was in crisis were more likely to have a low sense of political efficacy, a low belief in a just world, and a high degree of claims consciousness. These jurors also were more likely to be white, Protestant, and older. Considering all of the relationships among attitudinal scales together, it appears that it is disgruntled jurors who question most the legitimacy of civil litigation. The jurors who felt disenfranchised from government and low in their sense of political efficacy, those who had little belief that the world is just, and those who were aggressive in pursuing their own claims all expressed greater concerns about the civil justice system.

Although Protestants (and, in the regression analysis, whites) were slightly more likely to question the civil justice system, there was no consistent pattern showing that those from social groups that are typically considered to be disadvantaged, such as racial or religious minorities and the poor, were more or less likely to perceive a litigation crisis. It appears that it is the psychological predisposition of mistrust and alienation rather than the objective reality of privilege or disadvantage that promotes views of litigation crisis.

The significant correlation of religion to litigation crisis views was unexpected but intriguing. It may be that in the jurisdiction under study, Protestants possess certain characteristics or a unique history that predispose them to be hostile to civil litigation. Other studies have found religiosity to play a role in the derogation of suffering victims (Sorrentino \& Hardy, 1974), and in judgments about litigation (Greenhouse, 1989). Greenhouse, for example, found that Baptists in one Georgia town believed that disputing was inappropriate for Christians; they regarded "disputing and litigation as defining characteristics of the unsaved" (Greenhouse, 1989, p. 266).

The correlation between perceptions of a litigation crisis and the juror's age converges with the findings of the Harris poll (Taylor et al., 1987; see also Astolfo, 1991) and with Lawrence Friedman's (1985) contention that there has been an 
increase over time in people's expectations for full and fair compensation for victimization. If so, then it follows that younger jurors would see current litigation practice as more consistent with their expectations, while older jurors would express greater concerns about it.

It is, however, critical to reiterate that the correlations between Litigation Crisis attitudes and the other variables were all quite modest, and that the total percentage of variance accounted for in the regression analysis was small. Importantly, Litigation Crisis scores were unrelated to education or to income, suggesting that more knowledge about how the courts work, or a more favorable position in the nation's economy did not necessarily alter the view that civil litigation is out of control. Thus, there are detectable differences among subgroups in the population, but it appears that the belief that the litigation system is in crisis is a shared cultural truism, a social "fact." Concern about others seeking compensation for minor, contrived, or selfinflicted injuries, and getting something for nothing, appears to be a collectively shared feature of our individualistic culture rather than the province of any particular social group within society.

The work of Hayden (1991), Greenhouse (1989), and Engel (1984) indicates that people may be antagonistic toward litigation because they see it as violating important cultural values. Hayden (1991), for example, argues that using the courts to redress personal injury is perceived as violating values relating to individual responsibility, equality, and redistribution of wealth. When individual litigants bring the court into their disputes, they attempt to bypass personal responsibility for their injuries, and they undermine equality between the parties by putting the state on the side of the plaintiff. Compensating a person who has not "earned" the money is also at odds with Americans' dislike of financial redistribution by government action. The perceived links between litigation and these values may help to explain why the bulk of our respondents were so concerned about excessive lawsuits. However, it is important to note that most surveys examining attitudes toward the civil justice system have been conducted during the last decade, raising the possibility that concerns about civil litigation are limited to this time span.

In closing it is worthwhile discussing how the findings from this specialized sample of jurors might be similar to or different from the general population. Although the sample has produced unique insights by providing the views of actual jurors, because attitudes toward civil litigation were tapped after jury duty, jurors could have been influenced by their jury service. Studies of jurors show that the majority report more favorable attitudes toward the jury system and the legal system after they have served (Diamond, 1993).

To explore how the personal experiences of the jurors in deciding a civil lawsuit might have influenced the findings presented here, we analyzed Litigation Crisis attitudes and their relationship with demographic and attitudinal factors in two other data sets collected as part of the same research project. In the mock jury sample, 216 members of the same community as the actual jurors decided a slip-andfall case as mock jurors and completed a questionnaire that contained most of the items to which the actual jurors had responded. In the public opinion survey, 450 people from the state which included the jurors' community completed a telephone survey containing some of the same items as well as a scenario study featuring a civil lawsuit. Litigation Crisis attitudes were measured in the identical way for all three samples. 
In both the mock jury and the public opinion samples, the correlations between case judgments and Litigation Crisis attitudes were statistically significant, confirming the findings of Hans and Lofquist (1992) with tort jurors. For the mock jury sample, the attitudinal and demographic factors that were associated with Litigation Crisis views were similar although not identical to those found with actual jurors. A regression analysis showed that the mock juror's religion (as either Protestant or non-Protestant) and the mock juror's sense of political efficacy were significant predictors of Litigation Crisis judgments. These were among the strongest relationships found for actual jurors.

Comparison of the juror sample with the public opinion sample was complicated by the fact that some items, including those from the Political Efficacy and the Locus of Control scales, were not included in the opinion survey because of time constraints. Thus it was not possible to compare the regression equations directly. However, examination of the public opinion survey sample's correlations between demographic and attitudinal items on the one hand and the Litigation Crisis scale scores on the other, revealed that the variables of authoritarianism, political identification, education, and race were significantly associated with Litigation Crisis attitudes. Conservatives, whites, those with more education, and those with more authoritarian viewpoints were more likely to believe in the litigation crisis. It will be recalled that education and income also related to views of the civil justice system in the Harris survey (Taylor et al., 1987). Although authoritarianism, political identification, and education were related to litigation crisis perceptions in the public opinion survey, they were not significant predictors of litigation crisis views among the actual (or the mock) jurors.

Taking all of the findings together, it seems that when those in positions of privilege, such as whites and those with more education and income, respond within the more detached context of telephone surveys, they may judge litigation to constitute an attack on the status quo. However, when faced with the same questions after the more direct and involving experience of jury service or even participation in a mock jury study, the symbolic aspects of civil litigation may be attenuated by case-specific considerations and by the responsibilities associated with jury service. That jury experience can alter views of litigation is supported by the fact that Litigation Crisis scores for the public opinion respondents were higher $(M=24.71)$ than the scores of actual jurors $(M=23.24)$ and mock jurors $(M=23.05)$.

There is an alternative possibility that differences between public opinion respondents and jurors can be explained by the self-selection of individuals into actual and mock jury service. Indeed, because civic participation and political efficacy are related (Renshon, 1974), jury service is more likely to be undertaken by those with higher levels of political efficacy, one of the major explanatory factors in jurors' litigation crisis judgments. We cannot fully explore this alternative because the political efficacy items were not included in the public opinion survey. However, the comparative analysis suggests why somewhat different factors may predict litigation crisis ideology in different contexts, and why it is crucial to study these issues with a range of samples and settings.

Despite some differences in the correlates of litigation crisis judgments across the three different samples, it is important to note three very significant commonalities. First, Litigation Crisis views were endorsed by majorities of all groups. Second, the proportion of variance accounted for in regression analyses was modest (multiple 
$R$ 's were $.36, .27$, and .30 for the juror, mock juror, and public opinion survey samples), indicating that litigation crisis views are shared by many demographic and attitudinal subgroups. Finally, in all three samples litigation crisis views were significantly correlated with case judgments. Thus the belief in a litigation crisis appears to be a significant part of contemporary legal culture that affects the outcomes of civil lawsuits.

The results reported here have some practical implications for attorneys on both sides of civil disputes. First, beliefs in the litigation crisis might well influence decisions in civil cases, by shaping views of the legitimacy of injured plaintiffs and by prompting jurors to consider the society-wide consequences of high jury awards. Second, the best way to determine whether prospective jurors hold such views is to ask them directly about the matter during voir dire. The small correlations between demographic variables and Litigation Crisis scores indicate that exercising peremptories on the basis of demographic characteristics alone to promote more favorable views of civil litigation is likely to be futile.

The commonality of views across different subgroups of jurors in the current study suggests that directly confronting the litigation crisis issue during the trial is desirable. When the theme of litigation crisis is integrated into trial strategy, it is likely to fall on responsive ears. Defense counsel might successfully incorporate such themes into their arguments and cross-examination of personal injury victims, while plaintiffs' attorneys will need to counteract jurors' predispositions to question their clients' legitimacy and to perceive the litigation system as out of control.

\section{REFERENCES}

Acock, A. C., \& Clarke, H. D. (1990). Alternative measures of political efficacy: Models and means. Quality and Quantity, 24, 87-105.

Aish, A.-M., \& Joreskog, K. G. (1990). A panel model for political efficacy and responsiveness: An application for LISREL 7 with weighted least squares. Quantiry and Quality, 24, 405-426.

Astolfo, T. A. (1991). Attitudinal predictors in a negligence case, Unpublished Masters' thesis, Florida International University, Miami, FL.

Campbell, A., Gurin, G., \& Miller, W. E. (1954). The voter decides. Evanston, IL: Ron Peterson \& Co.

Daniels, S. (1989). The question of jury competence and the politics of civil justice reform: Symbols, rhetoric, and agenda-building. Law and Contemporary Problems, 52, 269-310.

Daniels, S., \& Martin, J. (1986). Jury verdicts and the "crisis" in civil justice. Fustice System foumal, $11,321-348$.

Delisa, A., Moran, G., \& Cutler, B. L. (1992, March 13). Measuring attitudes toward tort reform and its consequences for juror verdicts. Paper presented at the biennial midwinter meeting of the American Psychology-Law Sociery, San Diego, CA.

Diamond, S. S. (1993). What jurors think: Expectations and reactions of citizens who serve as jurors. In R. E. Litan (Ed.), Verdict: Assessing the civil jury system (pp. 282-305). Washington, DC: The Brookings Institution.

Engel, D. M. (1984). The oven bird's song: Insiders, outsiders, and personal injury in an American community. Law and Society Review, 18,551-582.

Fleming, J. J., \& Schwarz, L, C. (1991, December). Juror opinion survey reveals obstacles for litigators. Inside Litigation, 5, 21-24.

Friedman, L. (1985). Total justice. New York: Russell Sage.

Galanter, M. (1983). Reading the landscape of disputes: What we know and don't know (and think we know) about our allegedly contentious and litigious society. UCLA Laz Review, 31, 4-71.

Galanter, M. (1986). The day after the litigation explosion. Maryland Law Review, 46, 3-39.

Greene, E., Goodman, J., \& Loftus, E. F. (1991). Jurors attitudes about civil litigation and the size of damage awards. American University Law Review, 40, 805-820.

Greenhouse, C. J. (1989). Interpreting American litigiousness. In J. Starr \& J. F. Collier (Eds.), History 
and power in the study of law: New directions in legal anthropology (pp. 252-273), Ithaca, NY: Cornell University Press.

Grossman, J. B., \& Trubek, D. M. (Eds.) (1981). Special issue on dispute processing and civil litigation. Law of Saciety Review, 15, Whole Nos, 3-4.

Hans, V. P. (1993). Attitudes toward the civil jury: A crisis of confidence? In R. E. Litan (Ed.), Verdict: Assessing the civil jury system (pp, 248-281). Washington, DC: The Brookings Institution.

Hans, V. P., \& Lofquist, W. S. (1992). Jurors' judgments of business liability in tort cases: Implications for the litigation explosion debate. Law and Society Review, 26, 85-115.

Hayden, R. M. (1991). The cultural logic of a political crisis: Common sense, hegemony and the great American liability insurance famine of 1986. Studies in Lave, Politics, and Sociery, 11, 95-117.

Hensler, D. R. (1992, February-March). Taking aim at the American legal system: The Council on Competitiveness's agenda for legal reform. Fudicature, 75, 244-250.

Huber, P. (1988). Liability: The legal revolution and its consequences. New York: Basic Books.

Lefcourt, H. M. (Ed.). (1981-1984). Research with the locus of control construct. (Vols. I-III). New York: Academic Press.

Lerner, M. J. (1980) Belief in a just world: A fundamenzal delusion. New York: Plenum.

Levenson, H. (1981). Differentiating among internality, powerful others, and chance. In H. M. Lefcourt (Ed). Research with the locus of control construct, Vol. 1 (pp. 15-63). New York: Academic Press.

Loftus, E. F. (1979, January). Insurance advertising and jury awards. American Bar Association fournal, pp. $68-70$.

Taylor, H., Kagay, M. R., \& Leichenko, S. (1987), Public attitudes toward the civil justice system and tort law reform. [Survey conducted for Aetna Life \& Casualty by Louis Harris and Associates. Copy. available from Louis Harris and Associates, 630 Fifth Avenue, New York, NY 10111.]

Moran, G., \& Comfort, J. C. (1982). Scientific juror selection: Sex as a moderator of demographic and personality predictors of impanelled felony juror behavior. Foumal of Personality and Social Psychology, 43, 1052-1063.

National Jury Project. (1992). Jurytwork: Systematic techniques [Release 12]. New York: Clark Boardman.

Narby, D. J, Cutler, B. L., \& Moran, G. (1993). A meta-analysis of the association between authoritarianism and jurors' perceptions of defendant culpability. Fournal of Applied Psychology, 78, 34-42.

Olson, W. K. (1991). The litigation explosion: What happened when America unleashed the lazsuit. New York: Dutton.

Quayle, D. (1991, August 13). Remarks at the meeting of the American Bar Association, Atlanta, Georgia.

Renshon, S. A. (1974). Psychological needs and political behavior. New York: Free Press.

Saks, M. J. (1986). If there be a crisis, how shall we know it? Maryland Law Review, 46, 63-77.

Saks, M. J. (1992). Do we really know anything about the behavior of the tort litigation system-and why not? University of Pennsylvania Law Review, 140, 1147-1292.

Sanders, J., \& Joyce, C. (1990). "Off to the races": The 1980s tort crisis and the law reform process. Houston Law Review, 27, 207-295.

Sarat, A. (1977). Studying American legal culture: An assessment of survey evidence. Lavo and Society Review, 11, 427-488.

Sorrentino, R. M., \& Hardy, J. E. (1974). Religiousness and derogation of an innocent victim. fournal of Personality, 42, 372-382.

The Public Pulse. (1991, August). To sue or not to sue? Public backs liability reform. The Public Pulse, p. 6.

Vidmar, N. (1992). The unfair criticism of medical malpractice juries. Fudicature, 76, 118-124.

Vidmar, N., \& Schuller, R. A. (1987). Individual differences and the pursuit of legal rights: A preliminary inquiry. Law and Human Behavior, 11, 299-317.

Yankelovich, Skelly, \& White, Inc. (1978). Highlights of a national survey of the general public, judges, lawyers, and community leaders. In T. J. Fetter (Ed.), State courts; $A$ blueprint for the future (pp. 5-69). Williamsburg, VA: National Center for State Courts. 
Copyright of Behavioral Sciences \& the Law is the property of John Wiley \& Sons Inc. and its content may not be copied or emailed to multiple sites or posted to a listserv without the copyright holder's express written permission. However, users may print, download, or email articles for individual use. 